\title{
Causative Role of Grapevine Red Blotch Virus in Red Blotch Disease
}

\author{
Luz Marcela Yepes, Elizabeth Cieniewicz, Björn Krenz, Heather McLane, \\ Jeremy R. Thompson, Keith Lloyd Perry, and Marc Fuchs ${ }^{\dagger}$
}

First, second, and seventh authors: Plant Pathology and Plant-Microbe Biology Section, School of Integrative Plant Science, Cornell University, New York State Agricultural Experiment Station, Geneva, NY 14456; and third, fourth, fifth, and sixth authors: Plant Pathology and PlantMicrobe Biology Section, School of Integrative Plant Science, Cornell University, 334 Plant Science, Ithaca, NY 14853.

Current address of B. Krenz: Leibniz-Institut DSMZ-Deutsche Sammlung von Mikroorganismen und Zellkulturen GmbH, Inhoffenstraße 7 B, 38124 Braunschweig, Germany.

Accepted for publication 9 February 2018.

\begin{abstract}
Grapevine red blotch virus (GRBV) has a monopartite single-stranded DNA genome and is the type species of the genus Grablovirus in the family Geminiviridae. To address the etiological role of GRBV in the recently recognized red blotch disease of grapevine, infectious GRBV clones were engineered from the genome of each of the two previously identified phylogenetic clades for Agrobacterium tumefaciens-mediated inoculations of tissue culture-grown Vitis spp. plants. Following agroinoculation and one or two dormancy cycles, systemic GRBV infection was detected by multiplex polymerase chain reaction (PCR) in Vitis vinifera exhibiting foliar disease symptoms but not in asymptomatic vines. Infected rootstock genotype $\mathrm{SO} 4(\mathrm{~V}$. berlandieri $\times V$. riparia) exhibited leaf chlorosis and cupping, while infection was asymptomatic

V. rupestris), and V. rupestris. Spliced GRBV transcripts of the replicaseassociated protein coding region accumulated in leaves of agroinfected vines, as shown by reverse-transcription PCR; this was consistent with systemic infection resulting from virus replication. Additionally, a virus progeny identical in nucleotide sequence to the infectious GRBV clones was recovered from agroinfected vines by rolling circle amplification, cloning, and sequencing. Concomitantly, subjecting naturally infected grapevines to microshoot tip culture resulted in an asymptomatic plant progeny that tested negative for GRBV in multiplex PCR. Altogether, our agroinoculation and therapeutic experiments fulfilled Koch's postulates and revealed the causative role of GRBV in red blotch disease.
\end{abstract} in agroinoculated $110 \mathrm{R}(V$. berlandieri $\times V$. rupestris $), 3309 \mathrm{C}(V$. riparia $\times$
Additional keyword: therapeutics.
Vitis spp. make up one of the major fruit crops worldwide. Grape berries are consumed as fresh fruit and are grown for juice, wine, raisins, jam, and several byproducts. Grapevines can be infected by close to 80 virus species, some of which can affect vine health and cause serious economic losses by reducing vigor and yield, altering fruit juice chemistry, or shortening the productive lifespan of vineyards (Martelli 2014, 2017). Grapevine red blotch virus $(\mathrm{GRBV})$ is a relatively recently identified virus of grapevine (Cieniewicz et al. 2017a; Sudarshana et al. 2015). This virus has a monopartite, single-stranded DNA genome and is the type member of the genus Grablovirus in the family Geminiviridae (Varsani et al. 2017). GRBV is associated with red blotch, a disease recognized a decade ago in California (Calvi 2011; Cieniewicz et al. 2017a; Sudarshana et al. 2015). GRBV affects the profitability of vineyards by substantially reducing fruit quality and ripening (Cieniewicz et al. 2017a; Ricketts et al. 2017; Sudarshana et al. 2015). In redberried grapevine cultivars, foliar disease symptoms consist of red blotches early in the season. These symptoms can expand and coalesce across the leaf blade as the season progresses. In whiteberried grapevine cultivars, foliar disease symptoms generally

${ }^{\dagger}$ Corresponding author: M. Fuchs; E-mail: mf13@cornell.edu

Funding: This work was supported, in part, by the California Grape Rootstock Research Foundation and California Grape Rootstock Improvement Commission, the American Vineyard Foundation, the New York Grape and Wine Foundation, the California Department of Food and Agriculture and the United States Department of Agriculture-National Institute of Food and Agriculture-Critical Agriculture Research and Extension award 2015-67028-23512.

*The $\boldsymbol{e}$-Xtra logo stands for "electronic extra" and indicates that three supplementary figures are published online.

(c) 2018 The American Phytopathological Society involve irregular chlorotic areas that may become necrotic late in the season. Foliar symptoms usually appear first on older leaves at the base of the canopy in late spring or early summer (i.e., late May to June in the northern hemisphere), and are progressively seen toward the top of the canopy in later months (i.e., August to October in the northern hemisphere). Diseased vines may also show cupping of the leaf blade as well as, for red-berried Vitis vinifera cultivars, reddening of veins underneath the leaf blade (Cieniewicz et al. 2017a; Sudarshana et al. 2015).

The genome of GRBV consists of seven open reading frames (ORF), four in the virion-sense DNA and three in the complementarysense DNA (Cieniewicz et al. 2017a). A genetic variability study of GRBV populations revealed two phylogenetic lineages, with the majority of variants belonging to clade 2 and more divergent variants belonging to clade 1 (Krenz et al. 2014). GRBV is present in major grape-production regions of the United States (Cieniewicz et al. 2017a; Krenz et al. 2014; Poojari et al. 2013; Seguin et al. 2014; Sudarshana et al. 2015). It has also been described in Canada (Poojari et. al. 2017; Xiao et al. 2015), Switzerland (Reynard et al. 2018), South Korea (Lim et al. 2016), and India (GenBank accession number KU522121).

Extensive vineyard surveys showed a close association of GRBV with diseased vines (Al Rwahnih et al. 2013). However, this association did not demonstrate disease causality; therefore, we investigated the etiological role of GRBV in red blotch disease. Here, we report the causative relationship between GRBV and red blotch disease by curing infected grapevines and by satisfying Koch's postulates using GRBV infectious clones in agroinoculation experiments.

\section{MATERIALS AND METHODS}

Plant material. V. vinifera 'Cabernet Sauvignon', 'Cabernet franc', 'Syrah', 'Chardonnay', 'Pinot gris', 'Pinot noir', and 'Riesling' 
and rootstock genotypes $110 \mathrm{R}$ (V. berlandieri $\times V$. rupestris), 3309C $(V$. riparia $\times V$. rupestris $), \mathrm{SO} 4(V$. berlandieri $\times V$. riparia $)$, and $V$. rupestris were selected for this study. Canes from single mother vines that repeatedly tested negative for GRBV by multiplex polymerase chain reaction (PCR) (Krenz et al. 2014) were callused and grown in a greenhouse. The same mother vines also tested negative for grapevine leafroll-associated virus 1, grapevine leafroll-associated virus 2 (GLRaV-2), Grapevine leafrollassociated virus 3 (GLRaV-3), grapevine leafroll-associated virus 4, tomato ringspot virus, tobacco ringspot virus (TRSV), grapevine fanleaf virus (GFLV), Arabis mosaic virus (ArMV), and grapevine virus A (GVA) by double antibody sandwich enzyme-linked immunosorbent assay using specific antibodies (Bioreba AG) and by reverse-transcription (RT)-PCR with appropriate primers (Al Rwahnih et al. 2012; Osman et al. 2008). The absence of grapevine leafroll-associated virus 7 , grapevine virus B (GVB), and Agrobacterium vitis was also verified by PCR-based assays (Al Rwahnih et al. 2012; Johnson et al. 2013; Osman et al. 2008).

GRBV elimination by microshoot tip culture and micropropagation of grapevine plantlets in tissue culture. Shoot tips ( 2 to $3 \mathrm{~cm}$ in length) of actively growing, greenhouse-grown, potted GRBV-infected Cabernet franc vines were collected, disinfected, and established in tissue culture as previously described (Alzubi et al. 2012). Apical and axillary buds with adjacent stem tissue (approximately $0.5 \mathrm{~cm}$ in length) were dissected in sterile water containing cysteine (Sigma C7352) at $74 \mathrm{mg} /$ liter under a stereoscope. Apical or axillary buds were established on woody plant medium (Sigma M-6774) supplemented with B5 vitamins (Gamborg et al. 1976), sucrose (Sigma S5390) at $15 \mathrm{~g} / \mathrm{liter}$, cysteine at $37 \mathrm{mg} / \mathrm{liter}$, bactoagar (Becton Dickinson Microbiology 214010) at $7.2 \mathrm{~g} / \mathrm{liter}$, and 6-benzyladenine (BA) $(0.25 \mathrm{mg} /$ liter for $V$. vinifera cultivars and 0.5 to $1.0 \mathrm{mg} / \mathrm{liter}$ for rootstock genotypes). The $\mathrm{pH}$ of the medium was adjusted to 5.8. One bud explant was established per 25-by-150-mm borosilicate glass culture tube (Bellco 2011-25150). Explants were incubated under cool fluorescent light at $25 \pm 2{ }^{\circ} \mathrm{C}$ and 33 to $45 \mu \mathrm{Em}^{-2} \mathrm{~s}^{-1}$ (16-h photoperiod). After 6 weeks, the apical meristem and the two adjacent axillary buds were transferred individually in glass tubes containing the same woody plant medium supplemented as described above but without BA. After two micropropagation cycles, asymptomatic plantlets with a normal growth were transferred to soil in the greenhouse, whereas plantlets exhibiting red blotch symptoms or an abnormal growth were destroyed by heat sterilization.

Plants established in the greenhouse were tested for virus elimination by monitoring disease symptoms and by multiplex PCR (Krenz et al. 2014) every 6 months and also after one or two dormancy periods for 2 months at $4 \pm 1^{\circ} \mathrm{C}$. The elimination rate was determined by counting the number of plants that were asymptomatic and tested negative for GRBV in multiplex PCR over the total number of plants tested following the microshoot tip therapeutics treatment.

Plants of the above-mentioned seven $V$. vinifera cultivars and four rootstock genotypes were similarly established and micropropagated in tissue culture for subsequent use in agroinoculation experiments.

Engineering of two GRBV infectious clones. Cultivars Merlot and Cabernet franc infected with GRBV variants NY175ab (clade 1, this study) and NY358 (clade 2, GenBank accession number JQ901105.2) (Krenz et al. 2014), respectively, were used to engineer infectious clones by rolling circle amplification (RCA) (Haible et al. 2006). GRBV-NY175ab (GenBank accession number MG672441) is a genetic variant isolated from the same Merlot vine as variant NY175 (GenBank accession number KF147916) (Krenz et al. 2014). RCA products were digested by restriction enzyme PstI (for NY358) or KpnI (for NY175ab) to produce full-length 3.2-kb fragments that were cloned into plasmid pUC19. A bitmer or partial tandem repeat of the GRBV genome was cloned using a two-step procedure of restriction digestion and ligation (Supplementary Fig. S1). The resulting clones were mobilized into A. tumefaciens strain C58C1 and referred to as the NY175ab and NY358 bitmer constructs. These GRBV clones consisted of a partial tandem duplication of the full-length genome of isolates NY175ab and NY358, such that sequences for two duplicated stem loop origins of replication flanked the remainder of the genome and adjoining sequences. The GRBV genomic sequence in the resulting pNY175ab and pNY358 bitmer constructs was determined by sequencing at the Genomics Facility of the Cornell University Biotechnology Resource Center prior to agroinoculation experiments.

Agroinoculation experiments with infectious clones of GRBV. Actively growing tissue culture-grown grapevines with five to six leaves (approximately 4- to 6-cm stem length) were selected for agroinoculation experiments with one of the two infectious GRBV clones in a laminar flow hood. First, tissue culture plantlets were sonicated for $1 \mathrm{~min}$ (Kurth et al. 2012) and roots were trimmed to about one-third in length using scissors that were immersed in a liquid suspension of recombinant A. tumefaciens cultures (optical density at $600 \mathrm{~nm}$ of approximately 1.0 ) containing $200 \mu \mathrm{M}$ acetosyringone and prepared as described (Kurth et al. 2012; Vaghchhipawala and Mysore 2008). Then, for vacuumassisted agroinoculation, four plantlets were transferred in 0.24liter Styrofoam disposable food cups (Konen Office Supplies $16 \mathrm{MJ} 32$ ) containing $150 \mathrm{ml}$ of the liquid agrobacterium suspension and a sterile metal mesh was placed on each container to maintain plantlets submerged in the bacterial solution. Two containers with 8 plantlets/treatment and 32 plantlets/construct were placed in a vacuum chamber for vacuum-assisted agroinfiltrations for 1 to $7 \mathrm{~min}$ at 650 to $720 \mathrm{~mm} \mathrm{Hg}$. After the vacuum treatment, plantlets were evaluated to ensure leaf water soaking but no physical damage to the stem during the procedure. Alternatively, sterile stainlesssteel insect pins (needle size 000 or minuten $0.15 \mathrm{~mm}$ in diameter; Bioquip 1208S000 and 1208SA) were dipped in agar cultures of A. tumefaciens and used for gentle pricking of stems, petioles, midribs, and primary leaf veins. This was done because GRBV, by analogy with other geminiviruses, is anticipated to be restricted to the phloem (Sudarshana et al. 2015). Following inoculation experiments, plantlets were transferred to sterile vermiculite in 1-liter clear polyethylene plastic containers with closed lids (Konen Office Supplies PK32T-C) and incubated under cool fluorescent light at $25 \pm 2{ }^{\circ} \mathrm{C}$ and 33 to $45 \mu \mathrm{Em}^{-2} \mathrm{~s}^{-1}$ (16-h photoperiod) for 8 to 16 weeks. Plantlets were monitored weekly for red blotch symptom development and subsequently transferred to soil in a greenhouse, as previously described (Alzubi et al. 2012), for further evaluation and testing.

A. tumefaciens strain GV3101 containing plasmid pBIN19 harboring the reporter gene $\beta$-glucuronidase (GUS) with an intron (Vancanneyt et al. 1990) was used to test the effect of varied factors on the efficacy of DNA delivery following vacuum-assisted agroinfiltration or pin pricking. Factors tested were (i) vacuum duration and pressure; (ii) viral silencing suppressors (VSR); that is, $2 \mathrm{~b}$ of cucumber mosaic virus (CMV) (Jin and Zhu 2010), p19 from tomato bushy stunt virus (TBSV) (Kontra et al. 2016), and p24 from GLRaV-2 (Li et al. 2017); and (iii) development stage of tissue culture-grown grapevine plantlets (4- to 6-week-old versus 6- to 8-week-old plantlets). Agrobacteria suspensions harboring a GUS intron and one of the VSR were mixed in a 1:1 ratio for agroinoculation experiments. Histochemical staining, as described below, was used to compare the effect of the different treatments on the efficacy of DNA delivery. A. tumefaciens strain GV3101 carrying pBIN19 was used as a negative control in agroinoculation experiments.

Histochemical staining of grapevine tissue. At 10 to 13 days following agroinoculation, plantlets were immersed in the 5-bromo-4-chloro-3-indoxyl- $\beta$-D-glucuronide cyclohexylammonium (X-Gluc) staining solution, vacuum infiltrated two to three 
times for 1 min with full vacuum release between replicated vacuum applications, and incubated overnight at $37^{\circ} \mathrm{C}$. After removal of the staining solution, plantlets were washed in absolute ethanol to remove chlorophyll and better visualize the GUS staining (Jefferson 1987). Strong and homogeneous histochemical GUS staining was used as a proxy for determining optimal conditions of DNA delivery in grapevine tissue.

Detection of GRBV in agroinoculated Vitis plants. After soil establishment and following one or two dormancy periods, the presence of GRBV was tested in leaves of agroinoculated vines by multiplex PCR. Total plant DNA was extracted using the H.P. Plant DNA Mini Kit (OMEGA Biotek). Primer pairs designed in the GRBV replicase-associated (Rep) coding region and coat protein (CP) coding region were used to detect the virus, and primers targeting the Vitis 16S ribosomal DNA was used as a reference control (Krenz et al. 2014). PCR amplicons were analyzed by electrophoresis on $2 \%$ agarose gels and staining with GelRED (Biotium). Expected GRBV Rep, CP, and 16S amplicons were 283, 231, and 105 bp in size, respectively (Krenz et al. 2014). Plants were also scored for typical red blotch symptoms.

GRBV was also detected in leaves of selected agroinoculated vines by RT-PCR using total RNA extracted with a Plant RNA kit (OMEGA Biotek) and specific primers designed to amplify a fragment of the predicted Rep transcripts with the OneStep Ahead kit (Qiagen). Primer GRBV-SPLFor 5'-TTACAAGGCAAATATTG GAATG-3' was used in RT-PCR with either primer GRBV-Clade1Rev 5'-CAAAATGAACTCTTCGTGGATC-3' or primer GRBVClade2Rev 5' -CAAAACGAACTCTACGTGGAAG-3' for plants inoculated with clade 1 and clade 2 GRBV infectious clones, respectively, to bridge a 163-bp spliced Rep region (Supplementary Fig. S2) predicted in genomic position 2,286 to 2,449

TABLE 1. Elimination of grapevine red blotch virus (GRBV) from infected Vitis vinifera 'Cabernet franc' vines by in vitro microshoot tip culture

\begin{tabular}{llcc}
\hline & & \multicolumn{2}{c}{ PCR for GRBV } \\
\cline { 3 - 4 } Vine $^{\mathrm{b}}$ & $N^{\mathrm{c}}$ & Asymptomatic & Symptomatic \\
\hline $\mathrm{A}$ & 10 & $0 / 2$ & $8 / 8$ \\
$\mathrm{~B}$ & 25 & $0 / 7$ & $18 / 18$ \\
$\mathrm{C}$ & 19 & $0 / 4$ & $15 / 15$ \\
Total & 54 & $0 / 13$ & $41 / 41$ \\
\hline
\end{tabular}

a Number of vines testing positive for GRBV by multiplex polymerase chain reaction (PCR)/total number of asymptomatic or symptomatic vines tested.

b Mother vines of Cabernet franc infected with GRBV.

${ }^{c}$ Number of vine progeny obtained after therapeutics. nucleotides (nt) (Krenz et al. 2014). Total RNA was used in RT-PCR without DNAse I digestion. RT-PCR products were resolved by electrophoresis on $2 \%$ agarose gels and visualized after staining with GelRED (Biotium). The expected size for GRBV amplicons of spliced Rep transcripts was 206 bp while the size of GRBV amplicons corresponding to unspliced Rep transcripts or to trace amounts of viral genomic DNA in total grapevine RNA was 369 bp.

Characterization of GRBV progeny in agroinfected Vitis plants by RCA and sequencing. To characterize the complete genomic nucleotide sequence of the GRBV progeny derived from the NY175ab and NY358 infectious clones, total nucleic extracts were prepared from agroinfected plants using a cetyltrimethylammonium bromide extraction procedure and subjected to RCA (Krenz et al. 2014). The amplified DNA were digested with the restriction enzyme KpnI, cloned into plasmid pUC19, and characterized by Sanger sequencing at the Genomics Facility of the Cornell University Biotechnology Resource Center. The full-length genomic nucleotide sequence of the GRBV progeny was compared with that of the infectious GRBV clones using Megalign of the DNASTAR Lasergene software suite, version 14.1.

\section{RESULTS}

Sanitation of infected vines and production of healthy, symptomless vines. Actively growing shoots of three potted vines of Cabernet franc infected with GRBV genetic variant NY358 were used to establish microshoot tips in tissue culture from apical or axillary buds and the adjacent stem tissue (approximately $0.5 \mathrm{~cm}$ in length). After establishment in the greenhouse and two dormancy cycles, several clean vines were obtained for the three mother vines. The average GRBV elimination rate was $24 \%$ (13 of 54) (Table 1). It is noteworthy that all 13 vines that tested negative for GRBV in PCR were asymptomatic whereas all 41 vines that tested positive for GRBV in PCR exhibited typical disease symptoms (Fig. 1). These results demonstrated that GRBV can be eliminated from infected vines using microshoot tip culture, a procedure that is routinely used in most centers dedicated to the production of clean grapevines (Golino et al. 2017; Maliogka et al. 2014). A lack of disease symptoms in vines cured from GRBV provided evidence of a causative role of GRBV in grapevine red blotch disease.

Agroinoculation-mediated delivery of a $G U S$ intron construct to Vitis spp. Experimental conditions for vacuum-assisted agroinoculation and agropricking were optimized using $A$. tumefaciens carrying a GUS intron (Supplementary Fig. S3). Optimal X-Gluc staining varied with the vacuum treatment and the grapevine genotype. For example, the vacuum treatment for Riesling was

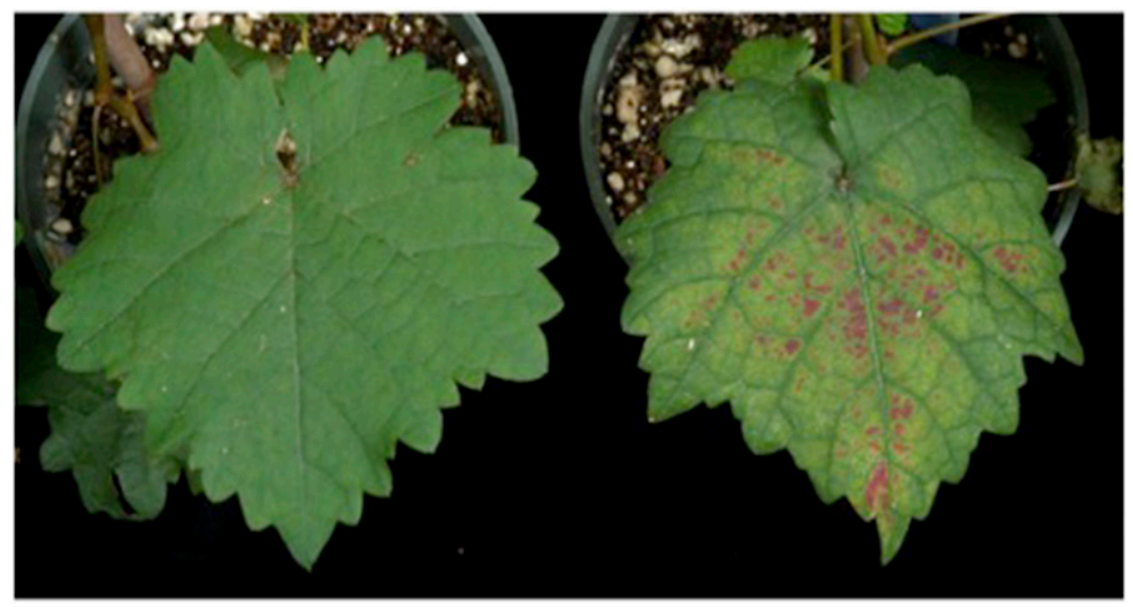

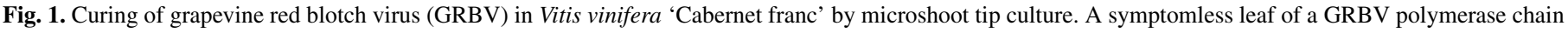
reaction (PCR)-negative vine (left) and a symptomatic leaf of a GRBV PCR-positive vine (right) after two dormancy periods posttherapeutics treatment. 
optimal at 5 to $7 \mathrm{~min}$ and 700 to $720 \mathrm{~mm} \mathrm{Hg} ; 1$ to $3 \mathrm{~min}$ and $680 \mathrm{~mm}$ $\mathrm{Hg}$ for Pinot noir and Pinot gris; 1.5 to $5 \mathrm{~min}$ and 650 to $700 \mathrm{~mm} \mathrm{Hg}$ for Cabernet franc; $5 \mathrm{~min}$ and $700 \mathrm{~mm} \mathrm{Hg}$ for Cabernet Sauvignon; $7 \mathrm{~min}$ and $720 \mathrm{~mm} \mathrm{Hg}$ for Chardonnay and Syrah; and $5 \mathrm{~min}$ and $700 \mathrm{~mm} \mathrm{Hg}$ for rootstock genotypes 3309C, SO4, 110R, and $V$. rupestris. The addition of VSR (i.e., CMV 2b, TBSV p19, and GLRaV-2 p24) to the Agrobacterium suspension had no effect on the efficacy of DNA delivery, as measured by X-Gluc staining (data not shown). In addition, 4- to 6-week-old plantlets were superior to 8- to 12-week-old plantlets in terms of X-Gluc staining; X-Gluc staining was not detected on older leaves and was uneven on older plantlets, in contrast to even distribution of X-Gluc staining on younger plantlets (data not shown). Therefore, only 4- to 6-weekold plantlets were used in subsequent experiments and VSR were not further included. Needle pricking was more labor intense than

TABLE 2. Infection of grapevines by grapevine red blotch virus (GRBV) after agroinoculation and agropricking with infectious clones of representative variants of GRBV clade 1 (NY175) and clade 2 (NY358)

\begin{tabular}{|c|c|c|c|c|c|}
\hline \multirow[b]{2}{*}{ Genotype } & \multirow[b]{2}{*}{$N^{\mathrm{c}}$} & \multicolumn{2}{|c|}{$\begin{array}{l}\text { GRBV PCR- } \\
\text { positive vines }^{\text {a }}\end{array}$} & \multicolumn{2}{|c|}{$\begin{array}{c}\text { Infected, } \\
\text { symptomatic vines }\end{array}$} \\
\hline & & NY175ab & NY358 & NY175ab & NY358 \\
\hline \multicolumn{6}{|l|}{ Vitis vinifera cultivars } \\
\hline Syrah & 47 & $6 / 14$ & $20 / 33$ & 6 & 20 \\
\hline Cabernet franc & 35 & $4 / 16$ & $3 / 19$ & 4 & 3 \\
\hline Cabernet Sauvignon & 37 & $2 / 12$ & $4 / 25$ & 2 & 4 \\
\hline Chardonnay & 93 & $10 / 13$ & $9 / 80$ & 10 & 9 \\
\hline Pinot noir & 32 & $3 / 11$ & $4 / 21$ & 3 & 4 \\
\hline Pinot gris & 22 & $\mathrm{nt}$ & $3 / 22$ & na & 3 \\
\hline Subtotal & 266 & $25 / 66$ & $43 / 200$ & 25 & 43 \\
\hline \multicolumn{6}{|l|}{ Rootstocks } \\
\hline $110 \mathrm{R}$ & 41 & $1 / 9$ & $3 / 32$ & 0 & 0 \\
\hline $3309 \mathrm{C}$ & 36 & $3 / 17$ & $4 / 19$ & 0 & 0 \\
\hline V. rupestris & 54 & $1 / 10$ & $7 / 44$ & 0 & 0 \\
\hline $\mathrm{SO} 4$ & 41 & $2 / 20$ & $6 / 21$ & 2 & 6 \\
\hline Subtotal & 172 & $7 / 56$ & $20 / 116$ & 2 & 6 \\
\hline Controls ${ }^{\mathrm{d}}$ & 72 & $0 / 29$ & $0 / 43$ & 0 & 0 \\
\hline
\end{tabular}

a Number of vines agroinoculated with GRBV NY358 and NY175ab infectious clones that tested positive for GRBV in multiplex polymerase chain reaction (PCR) after two dormancy periods/number of vines agroinoculated; $\mathrm{nt}=$ not tested

b Number of GRBV PCR-positive vines that displayed red blotch disease symptoms after two dormancy periods; na $=$ not applicable.

c Number of vines inoculated with the GRBV NY358 or the NY175ab infectious clone by vacuum-assisted agroinoculation and agropricking.

d Control vines were either agroinoculated with pBIN19 or mock inoculated. vacuum-assisted agroinoculation but resulted in strong X-Gluc staining at the delivery sites.

Agroinoculation-mediated delivery of GRBV and symptom development in inoculated vines. In an attempt to obtain direct evidence of the causative role of GRBV in grapevine red blotch disease, infectious bitmer clones of GRBV were engineered, one from each of the two phylogenetic clades (Krenz et al. 2014). Vacuum-assisted agroinoculation and agropricking under conditions effective for delivering the GUS intron construct were used to deliver infectious GRBV clones to tissue culture-grown grapevine. Overall, 266 plantlets of six $V$. vinifera cultivars and 172 plantlets of four rootstock genotypes were agroinoculated (Table 2). GRBVinfected and symptomatic vines were obtained when infectious clones were delivered by both agroinoculation and agropricking, with no apparent differences in efficiency. Therefore, data on disease symptom development and characterization of GRBV following agroinoculation were combined for the two delivery methods (Table 2).

Following agroinoculation with GRBV infectious clone NY175ab or NY358, some plants of red-berried cultivars Cabernet franc, Cabernet Sauvignon, Pinot noir, and Pinot gris exhibited in vitro typical foliar disease symptoms (i.e., red blotches 2 to 3 months postagroinoculation) (Fig. 2). After symptom manifestation, symptomatic leaves often dwindled and withered. No disease symptom was observed in vitro on white-berried cultivars Chardonnay and Riesling or on rootstocks compared with controls. Plantlets were subsequently transferred to soil and maintained in a greenhouse for further monitoring. Typical foliar disease symptoms were apparent on some vines, particularly vines of red-berried $V$. vinifera cultivars in the same growing cycle; however, the majority of the agroinoculated plants remained asymptomatic. Only after one or two dormancy periods did disease symptoms become pronounced, particularly on vines of red-berried $V$. vinifera cultivars. GRBVinfected vines exhibiting typical foliar disease symptoms were obtained for each of the $V$. vinifera cultivars tested. Typical foliar red blotches (Fig. 3A to D) or chlorotic interveinal areas (Fig. 3E) were observed for some plants of red-berried $V$. vinifera cultivars and the white-berried Chardonnay, respectively. Rootstocks did not manifest foliar disease symptoms (Fig. 3F to $\mathrm{H}$ ), regardless of whether the plants underwent a dormancy treatment or not, except SO4 (V. berlandieri $\times V$. riparia), which exhibited foliar chlorosis and cupping (Fig. 3I). Agroinfected vines exhibited typical foliar disease symptoms regardless of whether they were treated with the GRBV NY175ab or the NY358 infectious clone, with no apparent differences between the GRBV isolates. All control plants
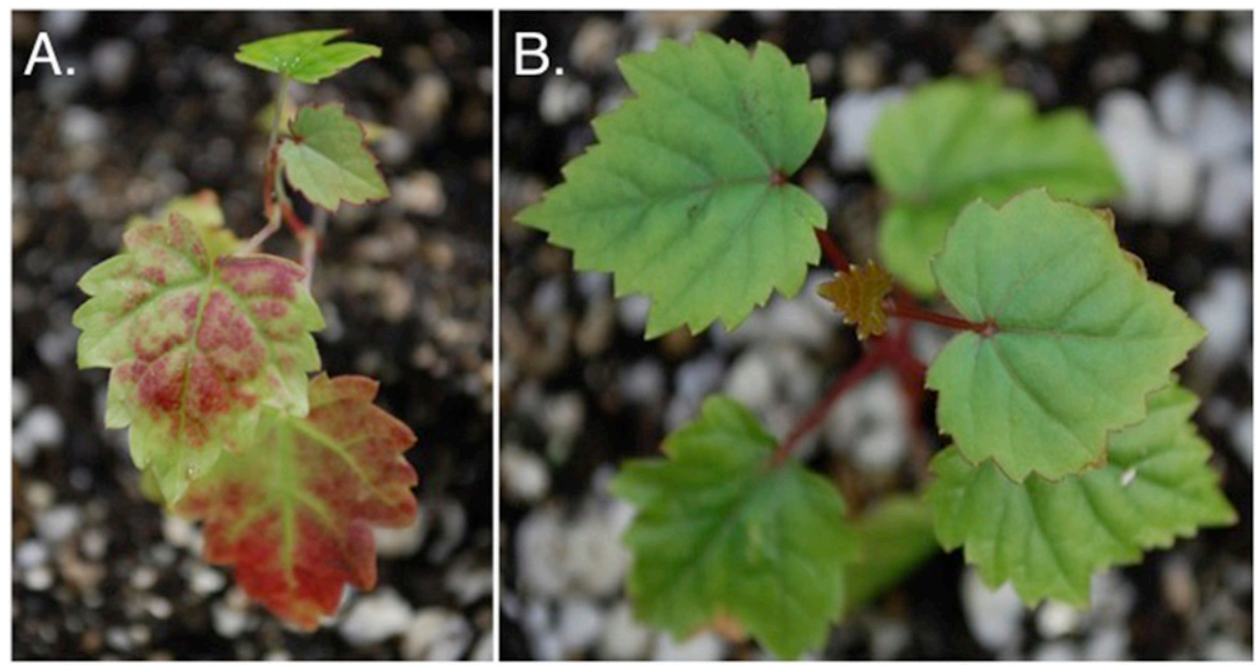

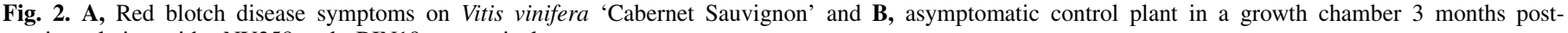
agroinoculation with pNY358 and pBIN19, respectively. 
agroinoculated with pBIN19 or mock inoculated remained symptomless for the duration of the trial (Table 2).

Characterization of GRBV by PCR in agroinoculated vines. The presence of GRBV was determined in agroinoculated vines by multiplex PCR (Table 2). The two DNA fragments of the expected size were amplified from at least four vines of each of the genotypes agroinoculated with either the GRBV NY175ab or the NY358 infectious clone (Fig. 4A). A strict correlation between foliar disease symptoms and presence of GRBV, as shown by multiplex PCR, was consistent for the $V$. vinifera cultivars $(n=68)$ but not in rootstock genotypes $(n=27)$, except for SO4 (Table 2). This demonstrated that symptoms could be ascribed to GRBV following virus delivery via agroinoculation to $V$. vinifera and $\mathrm{SO} 4$ plants. Initially, a very few agroinoculated vines tested positive for GRBV in PCR but were asymptomatic (2\%, 5 of 266) after a first dormancy cycle; however, symptoms became apparent in these vines after an additional dormancy cycle. Infection was latent for rootstocks $V$. rupestris, $110 \mathrm{R}(V$. berlandieri $\times V$. rupestris $)$, and
3309C (V. riparia $\times V$. rupestris) (Table 2). From the 438 agroinoculated plants (Table 2), the rate of infection detected by PCR was slightly higher for NY175ab (26\%, 32 of 122) compared with NY358 (20\%, 63 of 316) but considerably fewer vines were challenged with pNY175ab and only in the single cultivar Chardonnay was the higher infectivity apparent. Symptom appearance and severity were similar for both GRBV infectious clones. GRBV was never detected in any of the control plants that were agroinoculated with pBIN19 or mock inoculated (Table 2).

GRBV infection in agroinoculated vines resulted from virus replication. To ascertain that GRBV PCR amplicons resulted from virus replication in agroinoculated vines rather than from sequences present in A. tumefaciens that was still occurring in planta, an RT-PCR detection assay was applied using total RNA extracted from petioles with primers specifically designed to favor amplification of the predicted spliced Rep transcripts. Production and splicing of GRBV transcripts should only be detected in infected plant cells where the virus is replicating. Testing a subset of
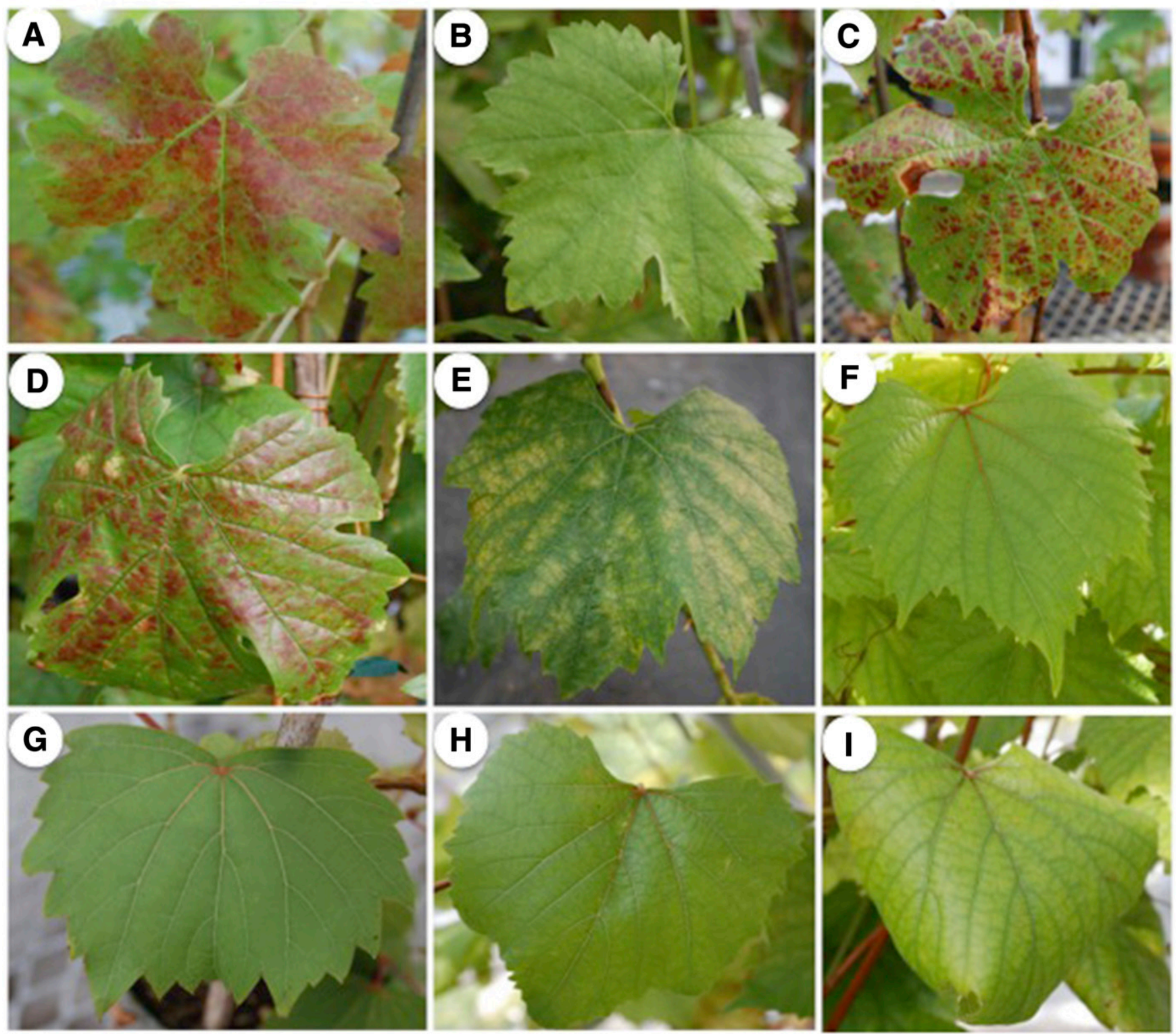

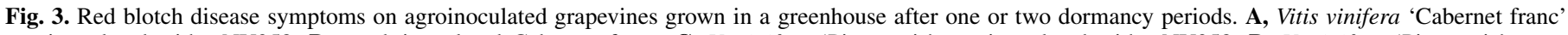

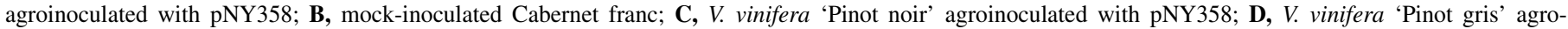

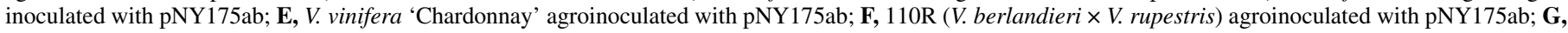

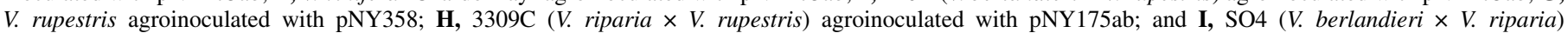

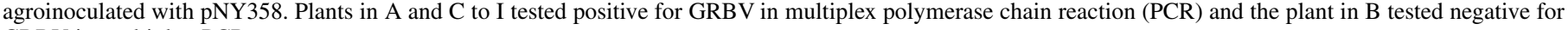
GRBV in multiplex PCR. 
agroinoculated vines by RT-PCR showed the anticipated 206-bp DNA product, as illustrated for Syrah vine 30 and Cabernet franc vine 29 (Fig. 4B). As expected, sequencing the corresponding RT-PCR amplicons revealed $100 \%$ nucleotide identity with the corresponding genomic Rep fragment for Syrah vine 30 (clade 2) and Cabernet franc vine 29 (clade 1), and confirmed the predicted splicing Rep sites. Accumulation of spliced Rep transcripts of expected size coincided with the accumulation of Rep sequences, corresponding to either the size of unspliced transcripts ( $369 \mathrm{bp}$ ) or GRBV genomic DNA present in trace amounts in grapevine total RNA (Fig. 4B, lanes 1, 2, and 4). Together, these results revealed the occurrence of GRBV replication in agroinoculated vines.

Integrity of virus progeny recovered from plants agroinoculated with the two GRBV infectious clones. Two Syrah vines ( $4 n$ and 22n), agroinfected with the GRBV NY175ab infectious clone, were selected to characterize the GRBV progeny. Petioles from these two vines were sampled approximately 18 months postagroinoculation, after one dormancy cycle, and characterized by RCA, cloning, and sequencing. The sequence of the virus progeny from both plants showed complete identity to the GRBV NY175ab infectious clone over the 3,205-nt genome.

The sequence of the clade 2 GRBV isolate NY358 was initially described as GenBank accession JQ901105. After the construction and insertion of a tandem clone in the binary vector pBIN19, the GRBV genomic sequence in the resulting pNY358 construct was determined. Three differences were noted compared with the sequence available in GenBank: a silent T892G substitution, a T1912C substitution encoding an Arg to Gly change in the C2 ORF, and an A2557G substitution encoding a Val to Ala change in the C1 ORF. Three vines agroinfected with the GRBV NY358 infectious clone (Syrah vine 2, Chardonnay vine 22, and Cabernet Sauvignon vine 29) were selected for analysis of virus progeny by RCA, cloning, and sequencing. These three vines were sampled approximately 18 months after agroinoculation and a dormancy cycle. The sequence of the GRBV progeny in the three tested agroinfected vines was identical to that in the NY358 construct.

These results revealed the integrity of the GRBV progeny in vines agroinfected with the NY358 and NY175ab infectious clones. No indels or point mutations were observed in the virus progeny compared with the sequence of the infectious clones.

\section{DISCUSSION}

Koch's postulates (Koch 1876) are foundational in pathology to establish the causative relationship between a pathogen and a disease. The first postulate theorizes that the microorganism must be present in most if not all cases of the disease; for GRBV, this association was documented earlier (Al Rwahnih et al. 2013). The second postulate advances that the microorganism must be isolated from the diseased host and grown in pure culture; the proxy step for nonculturable organisms was achieved by engineering infectious GRBV clones (this study) to circumvent the inability to maintain plant viruses, including GRBV, in pure cultures. For the third postulate, the microorganism from the pure culture must cause the same disease when inoculated into a healthy, susceptible host. This was attained using the two GRBV infectious clones to agroinoculate vines, of which some became infected and exhibited foliar disease symptoms, reproducing the original disease (Table 2; Figs. 2, 3, and 4). In addition, detecting the accumulation of spliced transcripts of the Rep protein in agroinoculated, symptomatic vines demonstrated replication of GRBV (Fig. 4B). Finally, a fourth postulate now considered to be part of Koch's postulates (Fredericks and Relman 1996) states that the microorganism must be reisolated from the new diseased host, and shown to be the same as the original inoculated microorganism; this was accomplished by showing that the nucleotide sequence of the GRBV progeny in agroinfected vines was identical to that of the infectious clones. In summary, our experiments to deliver infectious clones of GRBV via vacuumassisted agroinoculation and agropricking fulfilled Koch's postulates and showed that GRBV is the causal agent of grapevine red blotch disease. These findings were confirmed by therapeutic experiments in which GRBV PCR-negative vines no longer exhibited foliar disease symptoms following microshoot tip culture. To our knowledge, this research is the first to satisfy Koch's postulates for a virus in a woody perennial plant using agroinoculation.

Recently, the three-cornered alfalfa treehopper, Spissistilus festinus (Say), was documented as a vector of GRBV in the laboratory. In these experiments, $V$. vinifera 'Cabernet Sauvignon' vines exposed to viruliferous $S$. festinus displayed red blotch disease symptoms (Bahder et al. 2016). These results are consistent with the causal role of GRBV in red blotch disease. For grapevine viruses other than GRBV, Koch's postulates were satisfied more than 55 years ago for GFLV, the causal agent of fanleaf degeneration. Crude sap of infected vines was then used to establish pure GFLV cultures on Chenopodium amaranticolor, a systemic herbaceous host, and Xiphinema index, the ectoparasitic nematode vector, was used to transfer the virus from infected herbaceous hosts to healthy vines in which typical disease symptoms developed (Hewitt et al. 1962). Subsequently, infectious clones of two strains of GFLV were engineered and used in virus-host
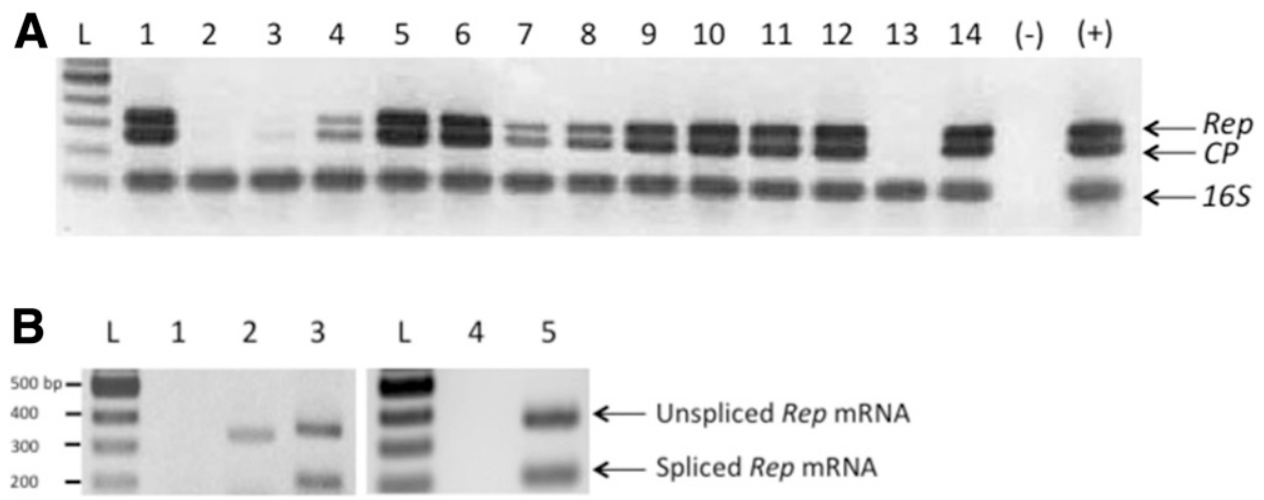

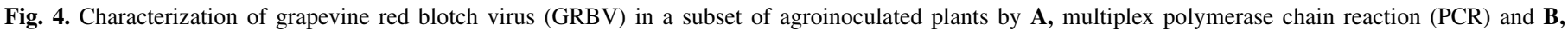

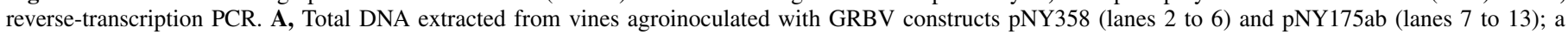

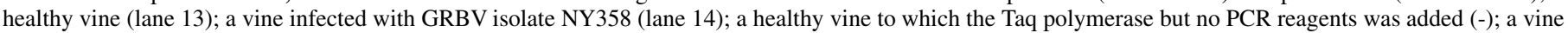

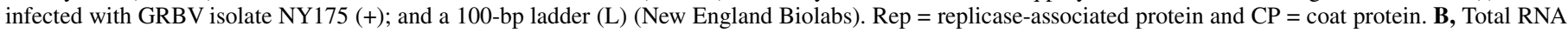

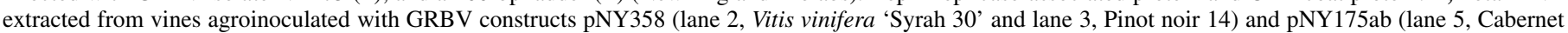

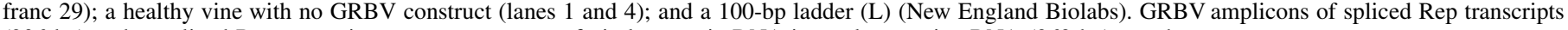
(206 bp) and unspliced Rep transcripts or trace amounts of viral genomic DNA in total grapevine RNA (369 bp) are shown. 
interaction studies (Vigne et al. 2013; Viry et al. 1993). More recently, an infectious clone of GLRaV-2 was engineered for agroinoculation of grapevines (Kurth et al. 2012). Similarly, infectious clones of GLRaV-3 (Jarugula et al. 2012), ArMV (Wetzel et al. 2013), GVA (Galiakparov et al. 1999), GVB (Moskovitz et al. 2008), grapevine Algerian latent virus (Lovato et al. 2014), grapevine Rupestris stem pitting-associated virus (Meng et al. 2013), TRSV (Zhao et al. 2015), and tomato black ring virus (Zarzyńska-Nowak et al. 2017) were described but no attempts to determine the etiological role of these viruses in corresponding grapevine diseases were reported. The work by Kurth et al. (2012) and ours is paving the way for virus delivery through agroinoculation in grapevine. Recently, infectious clones of Apple chlorotic leaf spot virus were agroinoculated to apple seedlings by vacuum infiltration (Zhang and Jelkmann 2017), expanding agroinoculation success stories for perennial crops.

For diagnostics and disease management, it is critical that efforts be directed to the causal agent of the disease (Golino et al. 2017; Maliogka et al. 2014). Because GRBV causes red blotch disease, there is no doubt that initiatives targeting the elimination of the virus from vine stocks in foundation vineyards and in propagative material, confirmed by PCR-based diagnostic assays, will have a positive impact on the sanitary status of the planting material. The importance of GRBV elimination initiatives is magnified because GRBV is causing severe losses. For example, the economic impact of GRBV is estimated to range from $\$ 8,855$ to $\$ 69,548$ per hectare over a 25-year lifespan of a Cabernet Sauvignon vineyard in Napa Valley in California (Ricketts et al. 2017). This illustrates the hardship caused by GRBV to growers and vintners alike (Cieniewicz et al. 2017a; Reynard et al. 2018; Sudarshana et al. 2015). Recently, spread of GRBV was documented in a diseased vineyard in California with a 1 to $2 \%$ incidence increase annually (Cieniewicz et al. 2017b), demonstrating the importance of optimal disease management strategies to reduce initial GRBV inoculum.

Efforts to revise grapevine certification programs by adding GRBV to established standards are underway in North America. In the United States, New York was the first state to include GRBV in its certification program. California, Washington, Oregon, and Idaho are following suit. Because, thus far, GRBV has been reported only in the United States (Al Rwahnih et al. 2013; Krenz et al. 2014; Poojari et al. 2013; Seguin et al. 2014), Canada (Poojari et al. 2017; Xiao et al. 2015), Switzerland (Reynard et al. 2018), South Korea (Lim et al. 2016), and India (GenBank accession number KU522121), it is difficult to anticipate if and how certification programs outside North America will be amended to include GRBV.

Vines singly infected with GRBV obtained through agroinoculation will be useful to characterize the attributes of virus transmission by $S$. festinus. For such studies, vines singly infected with GRBV will be important for virus acquisition and transmission steps to be optimal. The agroinfected vines obtained in this study will provide a reliable source of GRBV with no other major grapevine viruses anticipated to interfere with the transmission assays. Advancing our understanding of the mode of GRBV transmission is critical to facilitate the development of optimal disease management strategies.

\section{ACKNOWLEDGMENTS}

We thank D. MacUmber, F.-W. Choi, R. Cox, and A. Gauthier for the characterization of GRBV in agroinoculated grapevines; and Y. M. Cheung for plant care in the greenhouse and assistance with agroinoculation experiments. The memorandum of understanding and agreement number 15974 with the Cornell Institutional Biosafety Committee is acknowledged.

\section{LITERATURE CITED}

Al Rwahnih, M., Dave, A., Anderson, M., Rowhani, A., Uyemoto, J. K., and Sudarshana, M. R. 2013. Association of a DNA virus with grapevines affected by red blotch disease in California. Phytopathology 103:1069-1076.
Al Rwahnih, M., Osman, F., Sudarshana, M., Uyemoto, J., Minafra, A., Saldarelli, P., Martelli, G., and Rowhani, A. 2012. Detection of Grapevine leafroll-associated virus 7 using real time qRT-PCR and conventional RTPCR. J. Virol. Methods 179:383-389.

Alzubi, H., Yepes, L. M., and Fuchs, M. 2012. Enhanced micropropagation and establishment of grapevine rootstock genotypes. Int. J. Plant Dev. Biol. 6:9-14.

Bahder, B., Zalom, F., Jayanth, M., and Sudarshana, M. 2016. Phylogeny of geminivirus coat protein sequences and digital PCR aid in identifying Spissistilus festinus (Say) as a vector of Grapevine red blotch-associated virus. Phytopathology 106:1223-1230.

Calvi, B. L. 2011. Effects of red-leaf disease on Cabernet Sauvignon at the Oakville experimental vineyard and mitigation by harvest delay and crop adjustment. M.S. thesis, University of California, Davis.

Cieniewicz, E., Perry, K. L., and Fuchs, M. 2017a. Grapevine red blotch virus. Pages 303-314 in: Grapevine Viruses: Molecular Biology, Diagnostics and Management. B. Meng, G. P. Martelli, D. A. Golino, and M. F. Fuchs, eds. Springer Verlag, Cham, Switzerland.

Cieniewicz, E. J., Pethybridge, S. J., Gorny, A., Madden, L. V., McLane, H., Perry, K. L., and Fuchs, M. F. 2017b. Spatiotemporal spread of grapevine red blotch-associated virus in a California vineyard. Virus Res. 241: 156-162.

Fredericks, D. N., and Relman, D. A. 1996. Sequence-based identification of microbial pathogens: A reconsideration of Koch's postulates. Clin. Microbiol. Rev. 9:18-33.

Galiakparov, N., Tanne, E., Sela, I., and Gafny, R. 1999. Infectious RNA transcripts from grapevine virus A cDNA clone. Virus Genes 19:235-242.

Gamborg, O. L., Murashige, T., Thorpe, T. A., and Vasil, I. K. 1976. Plant tissue culture media. In Vitro 12:473-478.

Golino, D. A., Fuchs, M., Sim, S., Farrar, K., and Martelli, G. P. 2017. Improvement of grapevine planting stock through sanitary selection and pathogen elimination. Pages 561-579 in: Grapevine Viruses: Molecular Biology, Diagnostics and Management. B. Meng, G. P. Martelli, D. A. Golino, and M. F. Fuchs, eds. Springer Verlag, Cham, Switzerland.

Haible, D., Kober, S., and Jeske, H. 2006. Rolling circle amplification revolutionizes diagnosis and genomics of geminiviruses. J. Virol. Methods 135: 9-16.

Hewitt, W. B., Goheen, A. C., Raski, D. J., and Gooding, G. V. 1962. Studies on virus diseases of the grapevine in California. Vitis 3:57-83.

Jarugula, S., Gowda, S., Dawson, W. O., and Naidu, R. A. 2012. Development of full length infectious cDNA clone of grapevine leafroll-associated virus 3. Pages 70-71 in: Proc. 17th Congr. ICVG, Davis, CA.

Jefferson, R. 1987. Assaying chimeric genes in plants: The GUS gene fusion system. Plant Mol. Biol. Rep. 5:387-405.

Jin, H., and Zhu, J. K. 2010. A viral suppressor protein inhibits host RNA silencing by hooking up with Argonautes. Genes Dev. 24:853-856.

Johnson, K. L., Zheng, D., Kaewnum, S., Reid, C. L., and Burr, T. J. 2013. Development of a magnetic capture hybridization real-time PCR assay for detection of tumorigenic Agrobacterium vitis in grapevines. Phytopathology 103:633-640.

Koch, R. 1876. Untersuchungen über Bakterien: V. Die Ätiologie der Milzbrand-Krankheit, begründet auf die Entwicklungsgeschichte des $B a$ cillus anthracis. Beitr. Biol. Pflanzen 2:277-310.

Kontra, L., Csorba, T., Tavazza, M., Lucioli, A., Tavazza, R., Moxon, S., Tisza, V., Medzihradszky, A., Turina, M., and Burgyán, J. 2016. Distinct effects of p19 RNA silencing suppressor on small RNA mediated pathways in plants. PLoS Pathog. 12:e1005935.

Krenz, B., Thompson, J. R., McLane, H. L., Fuchs, M., and Perry, K. L. 2014. Grapevine red blotch-associated virus is widespread in the United States. Phytopathology 104:1232-1240.

Kurth, E. G., Peremyslov, W. W., Prokhneysky, A. I., Kasschau, K. D., Miller, M., Carrington, J. C., and Dolja, V. V. 2012. Virus-derived gene expression and RNA interference vector for grapevine. J. Virol. 86:6002-6009.

Li, M., Zhang, J., Feng, M., Wang, X., Luo, C., Wang, Q., and Cheng, Y. 2017. Characterization of silencing suppressor p24 of Grapevine leafrollassociated virus 2. Mol. Plant Pathol. 19:355-368.

Lim, S., Igori, D., Zhao, F., and Moon, J. S. 2016. First report of Grapevine red blotch-associated virus on grapevine in Korea. Plant Dis. 100:1957.

Lovato, A., Faoro, F., Gambino, G., Maffi, D., Bracale, M., Polverari, A., and Santi, L. 2014. Construction of a synthetic infectious cDNA clone of Grapevine Algerian latent virus (GALV-Nf) and its biological activity in Nicotiana benthamiana and grapevine plants. Virol. J. 11:186.

Maliogka, V., Martelli, G. P., Fuchs, M., and Katis, N. 2014. Control of viruses infecting grapevine. Pages 175-227 in: Advances in Virus Research, Vol. 91, Control of Plant Viruses. G. Loebenstein and N. Katis, eds. Elsevier, Oxford, United Kingdom. https://www.sciencedirect.com/science/article/ pii/S0065352714000098?via\%3Dihub

Martelli, G. P. 2014. Directory of virus and virus-like diseases of the grapevine and their agents. J. Plant Pathol. 96:1-128. 
Martelli, G. P. 2017. An overview of grapevine viruses, viroids, and the diseases they cause. Pages 31-46 in: Grapevine Viruses: Molecular Biology, Diagnostics and Management. B. Meng, G. P. Martelli, D. A. Golino, and M. F. Fuchs, eds. Springer Verlag, Cham, Switzerland.

Meng, B., Venkataraman, S., Li, C., Wang, W., Dayan-Glick, C., and Mawassi, M. 2013. Construction and biological activities of the first infectious cDNA clones of the genus Foveravirus. Virology 435:453-462.

Moskovitz, Y., Goszczynski, D. E., Bir, L., Fingstein, A., Czosnek, H., and Mawassi, M. 2008. Sequencing and assembly of a full-length infectious clone of grapevine virus B and its infectivity on herbaceous plants. Arch. Virol. 153:323-328.

Osman, F., Leutenegger, C., Golino, D., and Rowhani, A. 2008. Comparison of low-density arrays, RT-PCR and real time TaqMan $^{\circledR}$ in detection of grapevine viruses. J. Virol. Methods 104:211-219.

Poojari, S., Alabi, O. J., Fofanov, V. Y., and Naidu, R. A. 2013. A leafhoppertransmissible DNA virus with novel evolutionary lineage in the family geminiviridae implicated in grapevine redleaf disease by next-generation sequencing. PLoS One 8:e64194.

Poojari, S., Lowery, D. T., Rott, M., Schmidt, A. M., and Úrbez-Torres, J. R. 2017. Incidence, distribution and genetic diversity of Grapevine red blotch virus in British Columbia. Can. J. Plant Pathol. 39:201-211.

Reynard, J. S., Brodard, J., Dubuis, N., Zufferey, V., Schumpp, O., Schaerer, S., and Gugerli, P. 2018. Grapevine red blotch virus: Absence in Swiss vineyards and analysis of potential detrimental effect on viticultural performance. Plant Dis. 102:651-655.

Ricketts, K. D., Gomez, M. I., Fuchs, M. F., Martinson, T. E., Smith, R. J., Cooper, M. L., and Wise, A. 2017. Mitigating the economic impact of grapevine red blotch: Optimizing disease management strategies in U.S. vineyards. Am. J. Enol. Vitic. 68:127-135.

Seguin, J., Rajeswaran, R., Malpica-Lopez, N., Martin, R. R., Kasschau, K., Dolja, V. V., Otten, P., Farinelli, L., and Poogin, M. M. 2014. De novo reconstruction of consensus master genomes of plant RNA and DNA viruses from siRNAs. PLoS One 9:e88513.

Sudarshana, M. R., Perry, K. L., and Fuchs, M. F. 2015. Grapevine red blotchassociated virus, an emerging threat to the grapevine industry. Phytopathology 105:1026-1032.
Vaghchhipawala, Z. E., and Mysore, K. E. 2008. Agroinoculation: A simple procedure for systemic infection of plants with viruses. Methods Mol. Biol. 451:555-562.

Vancanneyt, G., Schmidt, R., Conner-Sanchez, A., Willmitzer, L., and Rocha-Sosa, M. 1990. Construction of an intron-containing marker gene: Splicing of the intron in transgenic plants and its use in monitoring early events in Agrobacterium-mediated plant transformation. Mol. Genet. Genomics 220:245-250.

Varsani, A., Roumagnac, P., Fuchs, M. F., Navas-Castillo, J., Moriones, E., Idris, I., Briddon, R. W., Rivera-Bustamante, R., Murilo Zerbini, F., and Martin, D. P. 2017. Capulavirus and Grablovirus: Two new genera in the family Geminiviridae. Arch. Virol. 162:1819-1831.

Vigne, E., Gottula, J., Schmitt-Keichinger, C., Komar, V., Ackerer, L., Rakotomalala, L., Lemaire, O., Ritzenthaler, C., and Fuchs, M. 2013. A strain specific segment of the RNA-dependent RNA polymerase of Grapevine fanleaf virus determines symptoms in Nicotiana species. J. Gen. Virol. 94:2803-2813.

Viry, M., Serghini, M. W., Hans, F., Ritzenthaler, C., Pinck, M., and Pinck, L. 1993. Biologically active transcripts from cloned cDNA of genomic grapevine fanleaf nepovirus RNAs. J. Gen. Virol. 74:169-174.

Wetzel, T., Chisholm, J., Dupuis-Maguiraga, L., Bassler, A., and Sanfaçon, H. 2013. In vitro and in vivo evidence for differences in the protease activity of two arabis mosaic nepovirus isolates and their impact on the infectivity of chimeric cDNA clones. Virology 446:102-111.

Xiao, H., Kim, W. S., and Meng, B. 2015. A highly effective and versatile technology for the isolation of RNAs from grapevines and other woody perennials for use in virus diagnostic. Virol. J. 12:171.

Zarzyńska-Nowak, A., Ferriol, I., Flak, B. W., Borodynka-Filas, N., and Hasiów-Jarosczewska, B. 2017. Construction of Agrobacterium tumefaciensmediated tomato black ring virus infectious cDNA clones. Virus Res. 230:59-62.

Zhang, F., and Jelkmann, W. 2017. Construction of full-length infectious cDNA clones of Apple chlorotic leaf spot virus and their agroinoculation to woody plants by a novel method of vacuum infiltration. Plant Dis. 101:2110-2115.

Zhao, F., Hwang, U. S., Lim, S., Yoo, R. H., Igori, D., Lee, S. H., Lim, H. S., and Moon, J. S. 2015. Complete genome sequence and construction of infectious full-length cDNA clones of tobacco ringspot nepovirus, a viral pathogen causing bud blight in soybean. Virus Genes 51:163-166. 